\title{
Fate of the Donor Blastodermal Cells Derived from the Central Disc, Marginal Zone and Area Opaca Transferred into the Recipient Embryos
}

\author{
Mitsuru Naito $^{1)}$, Akiko Sano ${ }^{1)}$, Yuko Matsubara ${ }^{1)}$, Takashi Harumi ${ }^{1)}$, \\ Takahiro Tagami ${ }^{1)}$, Michiharu Sakurai ${ }^{2)}$ and Takashi Kuwana ${ }^{3)}$ \\ 1) National Institute of Animal Industry, Tsukuba Norindanchi P.O. Box 5, \\ Ibaraki 305-0901, Japan \\ 2) National Institute of Animal Health, Kannondai 3-1-1, Tsukuba, Ibaraki 305-0856, Japan \\ ${ }^{3)}$ National Institute for Minamata Disease, Minamata, Kumamoto 867-0008, Japan
}

In order to trace the donor blastodermal cell movement in the recipient embryos, stage $\mathrm{X}$ blastodermal cells derived from the central disc (CD), marginal zone (MZ) and area opaca (AO) were transfected in vitro by lipofection using green fluorescent protein (GFP) gene as a marker and transferred them into recipient blastoderms. Expression of the GFP gene in the whole blastoderm was observed in all the embryos manipulated at day 1 of incubation. After that, the GFP gene expression decreased with the incubation period and at day 3 of incubation the GFP gene expression was detected only in the extra-embryonic membranes. The frequency of the GFP gene expression at day 3 of incubation was lower when the donor blastodermal cells were derived from the $C D$ compared with the $\mathrm{MZ}$ or $\mathrm{AO}$, probably due to the active cell proliferation in the recipient embryos. The GFP gene is very useful as a marker to trace cell movement for short-term, but stable incorporation into the donor cell chromosomes is necessary for long-term tracing.

Key words : chicken, blastodermal cell, GFP gene, gene expression, lipofection

\section{Introduction}

Somatic and germline chimaeric chickens can be produced by transfer of stage $\mathrm{X}$ (Eyal-Giladi and Kochav, 1976) blastodermal cells (Petitte et al., 1990). The blastodermal cells at this stage have the ability to contribute to the germline, ectodermal, mesodermal and endodermal lineages when they were transferred into recipient blastoderm (Watanabe et al., 1992). The stage X blastoderm is composed of an area pellucida (AP) and a peripheral area opaca (AO). The AP is subdivided into a central disc (CD) and a peripheral marginal zone (MZ). The development and differentiation ability of the blastodermal cells derived from these portions (CD, MZ and $\mathrm{AO}$ ) is, however, unknown when they are transferred into recipient blastoderms. The GFP gene can be used for tracing the cell movement in the early embryos as a

Received: August 1, 2000 Accepted : September 8, 2000

Corresponding author: Dr. Mitsuru Naito FAX:+81-298-38-8606 E-mail:mnaito@niai. affrc.go.jp 
marker, because the GFP gene expression can be detected in the live embryos continuously by using the embryo culture technique (Naito et al., 2000). The present experiment was performed to transfect blastodermal cells in vitro and elucidate the fate of the donor blastodermal cells derived from the $\mathrm{CD}, \mathrm{MZ}$ and $\mathrm{AO}$ in the recipient embryos using the GFP gene as a marker.

\section{Materials and Methods}

Fertilised eggs (stage X) of Barred Plymouth Rock (BPR) were broken and the blastoderm was isolated from the yolk. The blastoderm was then separated into three parts ; $\mathrm{CD}, \mathrm{MZ}$ and AO. The blastodermal cells of each portion (CD, MZ and AO) were dissociated by trypsin treatment and dispersed in cell culture medium (KAv-1 medium, Kuwana et al., 1996).

Transfection of blastodermal cells was carried out separately in each portion (CD, $\mathrm{MZ}$ and AO) in vitro by lipofection. Two $\mu l$ of DNA in circular form $(0.5 \mu \mathrm{g} / \mu l$, pEGFP-C 1, CLONTECH) was diluted by $2 \mu l \mathrm{KAv}-1$ medium without serum and $6 \mu l$ $(3 \mathrm{mg} / \mathrm{ml})$ SuperFect ${ }^{\mathrm{TM}}$ solution (QIAGEN) was added. After incubating them for 15 minutes, $30 \mu \mathrm{l}$ of blastodermal cell suspension ( $\mathrm{CD}, \mathrm{MZ}$ or $\mathrm{AO}$ ) was added, gently mixed and incubated at $38^{\circ} \mathrm{C}$ for 7 hours. The transfected blastodermal cells were washed with KAv-1 medium.

Recipient eggs (BPR) were broken and the thick albumen was removed from the yolk. The transfected donor blastodermal cells (about 2000 cells) were injected into the recipient blastoderm (Naito et al., 1991 b) and the manipulated embryos were incubated at $38^{\circ} \mathrm{C}$ for 4 days in host eggshells (Perry, 1988 ; Naito et al., 1990). Expression of the GFP gene was observed under a fluorescent microscope (MZFL III, Leica) through the aperture of the reconstituted egg (Naito et al., 2000).

\section{Results and Discussion}

Blastodermal cells derived from the $\mathrm{CD}, \mathrm{MZ}$ and $\mathrm{AO}$ were efficiently transfected in vitro by lipofection. At day 1 of incubation, expression of the GFP gene was observed efficiently in all the embryos manipulated (Table 1), although the expression sites in the recipient embryos were similar among the donor blastodermal cells derived from the $\mathrm{CD}, \mathrm{MZ}$ and AO (Fig. 1). Then, the GFP gene expressing cells were gradually lost over time from the incubation period. At day 3 of incubation, the expression rate of the GFP gene decreased to $66.7-80.0 \%$ (Table 1). The GFP gene expression was then observed only in the extra-embryonic membranes and no embryonic tissue expression was observed in any of the embryos. The GFP gene expression seems to be transient and long-term tracing of the donor cell movement in the recipient embryos was difficult by the method employed in this experiment, because circular form DNA was usually expressed extra-chromosomally and gradually disappeared during the first several days of incubation (Naito et al., 1991 a).

The frequency of the GFP gene expression in the extra-embryonic membranes at day 3 of incubation tended to be lower when the transfected blastodermal cells derived from the CD were transferred as donor cells. Probably, blastodermal cells derived from 
Table 1. Expression of the GFP gene in early chicken embryos following transfer of transfected blastodermal cells in vitro by lipofection

\begin{tabular}{|c|c|c|c|c|c|c|c|c|}
\hline \multirow{2}{*}{$\begin{array}{l}\text { Portion of } \\
\text { donor } \\
\text { blastoderm }\end{array}$} & \multirow{2}{*}{$\begin{array}{l}\text { Number } \\
\text { of } \\
\text { blasto- } \\
\text { derms } \\
\text { treated }\end{array}$} & \multicolumn{3}{|c|}{$\begin{array}{l}\text { Number (\%) of } \\
\text { blastoderms or } \\
\text { embryos that } \\
\text { expressed the } \\
\text { GFP gene }\end{array}$} & \multirow{2}{*}{$\begin{array}{l}\text { Number } \\
(\%) \text { of } \\
\text { embryos } \\
\text { developed } \\
\text { to stage } \\
18(\mathrm{H} \& \mathrm{H})\end{array}$} & \multicolumn{3}{|c|}{$\begin{array}{c}\text { Expression of the GFP gene } \\
\text { in stage } 18 \text { embryos } \\
\text { Number }(\%)\end{array}$} \\
\hline & & day 1 & day 2 & day 3 & & $\begin{array}{l}\text { Embryonic } \\
\text { and extra-em } \\
\text { embryonic } \\
\text { tissues }\end{array}$ & $\begin{array}{l}\text { Extra- } \\
\text { nbryonic } \\
\text { tissues } \\
\text { only }\end{array}$ & $\begin{array}{l}\text { No } \\
\text { expression }\end{array}$ \\
\hline $\mathrm{CD}$ & 9 & $\begin{array}{c}9 \\
(100.0)\end{array}$ & $\begin{array}{c}9 \\
(100.0)\end{array}$ & $\begin{array}{c}6 \\
(66.7)\end{array}$ & $\begin{array}{c}9 \\
(100.0)\end{array}$ & $\begin{array}{l}0 \\
(0.0)\end{array}$ & $\begin{array}{c}6 \\
(66.7)\end{array}$ & $\begin{array}{c}3 \\
(33.3)\end{array}$ \\
\hline $\mathrm{MZ}$ & 9 & $\begin{array}{c}9 \\
(100.0)\end{array}$ & $\begin{array}{c}9 \\
(100.0)\end{array}$ & $\begin{array}{c}7 \\
(77.8)\end{array}$ & $\begin{array}{c}7 \\
(77.8)\end{array}$ & $\begin{array}{l}0 \\
(0.0)\end{array}$ & $\begin{array}{c}5 \\
(71.4)\end{array}$ & $\begin{array}{c}2 \\
(28.6)\end{array}$ \\
\hline $\mathrm{AO}$ & 10 & $\begin{array}{c}10 \\
(100.0)\end{array}$ & $\begin{array}{c}10 \\
(100.0)\end{array}$ & $\begin{array}{c}8 \\
(80.0)\end{array}$ & $\begin{array}{c}9 \\
(90.0)\end{array}$ & $\begin{array}{c}0 \\
(0.0)\end{array}$ & $\begin{array}{c}8 \\
(88.9)\end{array}$ & $\begin{array}{c}1 \\
(11.1)\end{array}$ \\
\hline Control & 3 & $\begin{array}{l}0 \\
(0.0)\end{array}$ & $\begin{array}{c}0 \\
(0.0)\end{array}$ & $\begin{array}{l}0 \\
(0.0)\end{array}$ & $\begin{array}{c}3 \\
(100.0)\end{array}$ & $\begin{array}{l}0 \\
(0.0)\end{array}$ & $\begin{array}{c}0 \\
(0.0)\end{array}$ & $\begin{array}{c}3 \\
(100.0)\end{array}$ \\
\hline
\end{tabular}

$\mathrm{CD}$ : central disc $\mathrm{MZ}$ : marginal zone AO : area opaca Control : blastodermal cells without transfection were transferred.
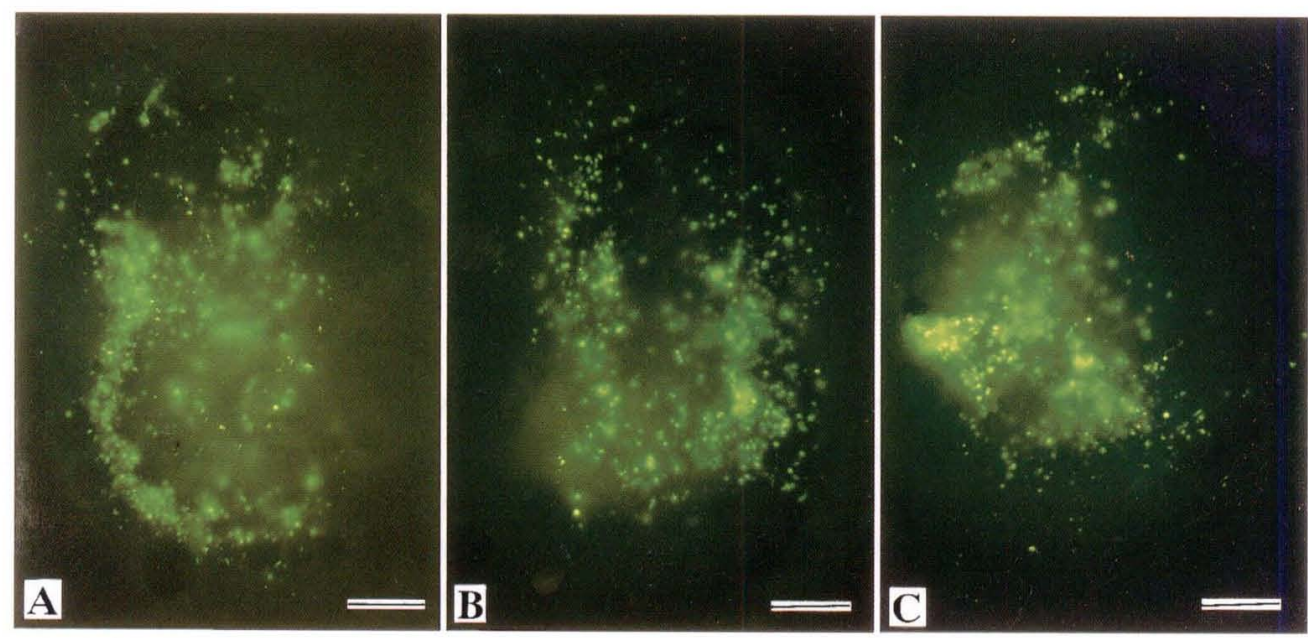

Fig. 1. Expression of the GFP gene in the blastoderms. Stage $\mathrm{X}$ blastoderms isolated from the yolk were separated into $\mathrm{CD}, \mathrm{MZ}$ and $\mathrm{AO}$, then transfected in vitro by lipofection. The transfected blastodermal cells were transferred into recipient blastoderms and incubated for 24 hours. The donor blastodermal cells were derived from the $\mathrm{CD}$ (A), MZ (B) and $\mathrm{AO}$ (C). Expression of the GFP gene was observed throughout the blastoderm in all the embryos manipulated. Scale bar represents $10 \mathrm{~mm}$. 
the $\mathrm{CD}$ proliferated more actively in the recipient embryos compared with those derived from the $\mathrm{MZ}$ or AO. The GFP gene introduced into the donor blastodermal cells diluted with the cell proliferation in the recipient embryos during the incubation period and this dilution was more frequent in the blastodermal cells derived from the CD compared with the $\mathrm{MZ}$ or AO. As a result, the GFP gene introduced into the blastodermal cells derived from the CD tended to disappear rapidly compared with the MZ or AO by the digestion with DNase in the cytoplasm (Fu et al., 1989). It is, however, unclear why the GFP gene was not expressed in all the embryonic tissues at day 3 of incubation.

The GFP gene is very useful as a marker because detection of the gene expression is easy and sensitive. In order to trace the donor cell movement in the recipient embryos for a long period, it is necessary to introduce the GFP gene into the donor cell chromosomes.

\section{Acknowledgements}

The authors are grateful to the staff of the Poultry Management Section of the National Institute of Animal Industry for taking care of the birds. This study was supported by the Special Funds from the Science and Technology Agency and the Ministry of Agriculture, Forestry and Fisheries of the Japanese Government. A part of this study was carried out by the Cooperative System for Supporting Priority Research.

\section{References}

Eyal-Giladi $\mathrm{H}$ and Kochav S. From cleavage to primitive streak formation : a complementary normal table and a new look at the first stages of the development of the chick. I. General morphology. Developmental Biology, 49 : 321-337. 1976.

$\mathrm{Fu} \mathrm{Y,} \mathrm{Hosokawa} \mathrm{K} \mathrm{and} \mathrm{Shiokawa} \mathrm{K.} \mathrm{Expression} \mathrm{of} \mathrm{circular} \mathrm{and} \mathrm{linealized} \mathrm{bacterial}$ chloramphenicol acetyltransferase gene with or without viral promoters after injection into fertilized eggs, unfertilized eggs and oocytes of Xenopus laevis. Roux's Archives of Developmental Biology, 198 : 148-156. 1989.

Kuwana T, Hashimoto K, Nakanishi A, Yasuda Y, Tajima A and Naito M. Long-term culture of avian embryonic cells in vitro. International Journal of Developmental Biology, $40: 1061$ -1064. 1996.

Naito M, Nirasawa $\mathbf{K}$ and Oishi T. Development in culture of the chick embryo from fertilized ovum to hatching. Journal of Experimental Zoology, 254 : 322-326. 1990.

Naito M, Agata K, Otsuka K, Kino K, Ohta M, Hirose K, Perry MM and Eguchi G. Embryonic expression of $\beta$-actin-lac $Z$ hybrid gene injected into the fertilized ovum of the domestic fowl. International Journal of Developmental Biology, $35: 69-75.1991 \mathrm{a}$.

Naito M, Watanabe M, Kinutani M, Nirasawa K and Oishi T. Production of quail-chick chimaeras by blastoderm cell transfer. British Poultry Science, 32 : 79-86. $1991 \mathrm{~b}$.

Naito M, Sano A, Tagami T, Harumi T and Matsubara Y. Efficient transfection of chicken blastoderms in vivo by lipofection and electroporation using green fluorescent protein gene as a marker. Animal Science Journal, $71: 377-385.2000$.

Perry MM. A complete culture system for the chick embryo. Nature, $331: 70-72.1988$.

Petitte JN, Clark ME, Liu G, Verrinder Gibbins AM and Etches RJ. Production of somatic and germline chimeras in the chicken by transfer of early blastodermal cells. Development, 108 : 185-189. 1990.

Watanabe $M$, Kinutani $M$, Naito $M$, Ochi $O$ and Takashima $Y$. Distribution analysis of transferred donor cells in avian blastodermal chimeras. Development, $114: 331-338.1992$. 